\title{
THE DISQUALIFICATION OF UNFIT DIRECTORS AND THE PROTECTION OF THE PUBLIC INTEREST
}

\author{
Stephen Griffin, Reader in Law, University of Wolverhampton
}

\section{INTRODUCTION}

In the utilisation and generation of wealth and employment opportunities the limited liability company is a most effective and necessary economic tool. By pursuing legitimate objectives geared to profit maximisation, a company, providing it acts within the law, not only serves to benefit its own shareholders and employees but also the general economic well being of the public interest. ${ }^{1}$ However, in circumstances where a company becomes insolvent, its potential demise and inability to discharge debts may inflict irreparable harm on society. The terminal decline of a company and the resulting non-repayment of corporate debts may severely prejudice corporate creditors and in addition may produce a spiralling decline in the fortunes of other individuals and businesses with interests related to the failed company or creditors of that company. Further, creditors will generally be precluded in respect of an ability to recover outstanding debts from the shareholders and directors of a company given that the company's limited liability status will ordinarily shield the company's human constituents from any responsibility in respect of the repayment of corporate debts. ${ }^{2}$

While corporate failure may be attributed to factors unrelated to managerial abuse or incompetence, ${ }^{3}$ corporate malaise is frequently caused or compounded by managerial error or wrongdoing. As business decisions often incorporate an element of risk it may be plausible for the law to excuse mere managerial error, but the law must seek to penalise intentional,

1 This may be considered as the accepted justification for corporate activity within a capitalist economy. However, profit maximisation may not always be beneficial to the public interest where, for example, the company is subject to a regulatory regime in which the calculation of profit fails to adequately consider the social costs of production. See further: Parkinson: Corporate Power and Responsibility (Oxford, Clarendon Press, 1993), especially, Chps 1 and 11.

2 As the majority of registered companies are incorporated with both a share capital and a limited liability status, the members of such companies will cease to incur any liability to contribute to the debts of the company following the payment to the company of the nominal value of their shares, see Salomon v A Salomon Ltd [1897] AC 22. At common law the corporate veil will only be removed to expose a company's human constituents to a liability to contribute to the debts of the company where the incorporation of the company is considered to be a fraud or sham, or where the company is considered to be but an agent of its controlling shareholder, see, Adams v Cape Industries [1990] Ch 433, Ord v Belhaven Pubs [1998] BCC 607 and Trustor AB v Smallbone [2001] 2 BCLC 436.

3 Business failure may be caused by circumstances beyond the control of a company's management, e.g., adverse fluctuations in national or global interest rates, the devaluation or overvaluation of currencies, trade union disputes unrelated to the particular business enterprise, trade embargoes resulting from international conflict, the unpredicted demise of a related industry, a shortage of skilled labour, natural disasters such as floods or fire, changes in government policy etc. 
reckless, or incompetent conduct, for a failure to penalise such delinquency will serve to weaken the creditability of the corporate entity and encourage others to abuse the advantages afforded by the concept of limited liability. ${ }^{4}$ To this end, the disqualification process, regulated by the Company Directors Disqualification Act 1986 (hereafter CDDA 1986) ${ }^{5}$ seeks to protect the public interest from the activities of delinquent directors. The purpose of the disqualification process is to weed out company directors who have abused their positions to the detriment of the public interest.

This paper is specifically directed at an examination of section 6 of the CDDA $1986,{ }^{6}$ a provision, which explicitly deals with the disqualification of directors, deemed to have been unfit in the management of insolvent companies. $^{7}$ The paper proposes a radical overhaul of the disqualification system with the ultimate objective of promoting a regime which more readily serves to protect the public interest. Such proposals seek to extend the ambit of reforms advanced in the recently enacted Insolvency Act $2000 .^{8}$

\section{Section 6 of the CDDA 1986}

Section 6(1) of the CDDA 1986 provides that the court is under a duty to impose a mandatory disqualification order against any person in circumstances where:

(a) that person is or has been a director of a company which has at any time become insolvent (whether while the person was a director or subsequently); and

(b) that person's conduct as a director of the company (either taken alone or taken together with the person's conduct as a director of another company or companies) makes the person unfit to be concerned in the management of a company.

In accordance with section 6(4) of the CDDA 1986, a contravention of section 6(1) results in a disqualification order for a minimum period of two years up to a maximum period of fifteen years. In addition to penalising an individual director by the removal of his capacity to act in the future management of a company, successful proceedings under section 6 may also serve to generally deter managerial conduct of a delinquent nature. The deterrent effect of a disqualification order may incorporate a director's fear of personal and professional humiliation, the loss of a future income earning

4 Although, under current legislative provisions, delinquent directors may be held personally accountable to contribute to the repayment of corporate debts, such legislation is, to a large extent, ineffectual. See generally, Griffin: The Personal Liability and Disqualification of Directors (Oxford, Hart Publishing, 1999).

5 The equivalent Northern Ireland legislation may be found in the Companies (Northern Ireland) Order 1989, Part II (hereafter the 1989 Order).

${ }^{6}$ Article 9 of the 1989 Order in Northern Ireland.

7 Statistics taken from Table D1 of the Department of Trade and Industry publication: Companies in 1999-2000 (HMSO) reveal that over 90 per-cent of all disqualifications imposed under the Companies Directors Disqualification Act 1986, are made under section 6.

8 This Act does not apply to Northern Ireland and there is no equivalent Northern Ireland legislation. 
capacity following the imposition of a disqualification order $^{9}$ and, in circumstances where an action is unsuccessfully defended, the incursion of substantial costs. ${ }^{10}$

\section{The Public Interest}

The primary purpose of section 6 of the CDDA 1986 is one which seeks to protect the public interest. ${ }^{11}$ During the period in which a director is subject to a disqualification order, the public interest will be protected by the removal of a director's capacity to repeat his past misconduct in respect of the future management of another company. In assessing whether a director represents a future threat to the public interest the courts are exclusively concerned with the nature and extent of the director's past conduct and the effect such conduct had on the interests of businesses and individuals who were directly or indirectly prejudiced as a consequence of the insolvent company's demise. The provision imposes a strict form of liability to the point whereby mitigating factors indicative of a director's potential to reform his future conduct will be discarded in determining whether a disqualification order should be imposed. ${ }^{12}$ Accordingly, unlike section 6's predecessor, namely section 300 of the Companies Act 1985, the court is not possessed of a general discretion to consider the likelihood of a director's ability to refrain from committing any future malpractice in the exercise of managerial responsibilities. Although it has been suggested that ". . the protective policy of disqualification would be advanced by a less technical view of unfitness that does not only look to the past" and that, "the legislation should require the courts to consider evidence as to whether the director is likely to be a future danger to the public," 13 it is submitted that the value of the mandatory two-year disqualification period required by section 6 is justifiable. The mandatory order promotes consistency and certainty in

9 A disqualification order may be detrimental to the economic well being of the professional director whose income will be dependant upon holding a managerial position, but its effect is likely to be less extreme in relation to the small businessman who, following disqualification, may decide to continue to operate a business through the medium of a business partnership or as a sole trader.

10 The costs are likely to be higher than any fine imposed in a criminal court However, legal aid may be available to a defendant who is made subject to disqualification proceedings. See further, Birch, "Legal Aid for Directors Disqualification Proceedings" (2001) 151 NLJ 1063.

11 CDDA 1986, s 7 provides that, "If it appears to the Secretary of State that it is expedient in the public interest that a disqualification order under s 6 should be made against any person, an application for the making of such an order against that person may be made ... (a) by the Secretary of State, or (b) if the Secretary of State so directs in the case of a person who is or has been a director of a company which is being wound up by the court in England and Wales, by the Official Receiver." Article 10 of the 1989 Order is the Northern Ireland equivalent.

12 However, factors indicative of a potential to reform may be considered as mitigating factors in respect of the courts' determination of appropriate disqualification periods. For judicial comments relating to issues concerning mitigation see e.g., Re Sevenoaks Stationers (Retail) Ltd [1991] Ch 164 at p 177, Re Pamstock Ltd [1996] BCC 341 at p 349 and Re Westmid Packing Services Ltd [1998] 2 All ER 124 at p 133.

13 See Hicks, "Director Disqualification: Can it Deliver?" [2001] JBL 433 at 447. 
respect of a positive requirement on the part of the courts to disqualify directors in circumstances where their conduct in the management of a company is considered to have been unfit. Indeed, if it was otherwise, judgments advancing judicial speculation as to a director's potential to reform past misconduct could seriously encourage a disturbance of the deterrent value attached to section 6 . The following statement taken from the judgment of Henry LJ in Re Grayan Building Services Ltd, ${ }^{14}$ amplifies this point:

"The concept of limited liability and the sophistication of our corporate law offers great privileges and great opportunities for those who wish to trade under that regime. But the corporate environment carries with it the discipline that those who avail themselves of those privileges must accept the standards laid down and abide by the regulatory rules and disciplines in place to protect creditors and shareholders. . . . The Parliamentary intention to improve managerial safeguards and standards for the long term good of employees, creditors and investors is clear. Those who fail to reach those standards and whose failure contributes to others losing money will often be plausible and capable of inspiring initial trust, often later regretted. Those attributes may make them attractive witnesses. But as section 6 makes clear, the court's focus should be on their conduct - on the offence rather than the offender." 15

In a wider sense, the protection of the future public interest may also encompass a consideration of the business interests of a regional or national economy or, given the prominence of the international market, may even incorporate business considerations of a global nature. The term "public interest" may also be interpreted to include the interests of a society, which in a political and economic context relies, in terms of its ability to function, on a free-market capitalist structure. ${ }^{16}$ In this sense the disqualification system may serve to protect the free market system from unfair manipulation in so far as it affords society a measure of confidence, fairness and transparency in the legal system's ability to police and weed out directors who have abused and exploited the advantages afforded by the incorporation of a limited liability company. ${ }^{17}$

14 [1995] BCC 554.

15 Ibid at $\mathrm{p} 577$.

16 For a discussion on the meaning of the term "public interest" in the general context of insolvency law see, Keay, "Insolvency Law: A Matter of Public Interest?" (2000) 51 NILQ 509.

17 See further: IF Fletcher, "The Genesis of Modern Insolvency Law - An Odyssey of Law Reform" [1989] JBL 365, at p 372. For a general discussion of theoretical justifications concerning the need for state intervention in the regulation of the market place, see A.Ogus, Regulation: Legal Form and Economic Theory (Oxford, Clarendon Press, 1994). 


\section{Conduct of an Unfit Nature}

Section 9 of the CDDA $1986^{18}$ provides that in assessing whether a director is unfit to act in the management of a company, the courts must have particular regard to the matters set out in both Part 1 and Part 2 of Schedule 1 to the CDDA 1986. ${ }^{19}$ However, as section 9 directs the court to have particular regard to the matters contained in Schedule 1, it is possible for conduct establishing a director's unfitness to be found in circumstances other than those governed by the Schedule. ${ }^{20}$

As the concept of unfit conduct is absent of any precise meaning or definition, the ability of a court to label a particular course of business malpractice as "unfit" will ultimately depend upon the individual circumstances and facts of a given case and as such it is impossible to prescribe a minimum standard of misconduct to which the label "unfit conduct" can be equated. Indeed, in Re Sevenoaks Stationers (Retail) Ltd, ${ }^{21}$ the Court of Appeal noted that the true question to be tried in section 6 proceedings was a question of fact. Dillon LJ expressed the nature of this question as one which,

18 Article 12 of the 1989 Order in Northern Ireland.

19 The matters mentioned in Part 1 of Schedule 1 require the court to consider, inter alia, the extent of a director's responsibility for: (a) any misfeasance or breach of duty in relation to a specified company; (b) the misapplication or retention of any money or property of the company; (c) corporate transactions contrary to Part XVI of the Insolvency Act 1986 (provisions against debt avoidance); (d) the company's failure to keep adequate accounting records and make annual returns; (e) the administration and updating of registers relating to directors and members and the creation of company charges. The matters mentioned in Part 2 of Schedule 1 govern a situation where a company is insolvent and require the court to consider, inter alia, the extent of a director's responsibility for: (a) the causes of the company's insolvent state; (b) any failure by the company to supply any goods or services which have been paid for (in whole or in part); (c) the company entering into any transaction or giving any preference liable to be set aside under IA 1986, s 127 or ss $238-240$ or challengeable under ss 242 or 243 (or any rule of law in Scotland); (d) any failure by the directors of the company to comply with IA 1986, s 98 (duty to call creditors meeting in creditors voluntary winding up); (e) any failure by the director to comply with any obligation imposed on him by IA 1986 , s 22 (company's statement of affairs in administration), s 47 (statement of affairs to administrative receiver), s 66 (statement of affairs in Scottish receivership), s 99 (directors' duty to attend meeting; statement of affairs in creditors' voluntary winding up), s131 (statement of affairs in winding up by the court); (f) s 234 (duty of any one with company property to deliver it up), s 235 (duty to co-operate with liquidator, etc.). The equivalent Northern Ireland provisions are in Parts 1 and 2 of Schedule 1 to the 1989 Order.

20 Such matters may include: a director's connection with other failed companies, a director's failure to take positive steps to correct management errors, a director's failure to resign from office where that step was the only viable option open to him, a director's failure to co-operate with a liquidator (see, Secretary of State for Trade and Industry v McTighe and Egan [1997] BCC 224) and a director's potential culpability under IA 1986, s 216, see Re Migration Services International Ltd (1999) The Times, 2nd December.

21 [1991] Ch 164. This was the first case in which the Court of Appeal was asked to consider the appropriateness of a disqualification order under CDDA 1986, s 6. 
“. . . used to be pejoratively described in the Chancery

Division as 'a jury question'."’22

In the identification of unfit conduct, the courts have expressed an unwillingness to impose a disqualification order in a situation where a director's culpability is attributable to imprudent business practices, albeit that such conduct was of an improper standard. ${ }^{23}$ Further, although a director's business practices may have been improper, it is unlikely that a director will be deemed unfit in circumstances where he acted honestly in seeking to prevent or minimise any loss to creditors. ${ }^{24}$ Instead, the courts have equated unfit conduct with conduct of a commercially culpable nature to the extent that the conduct, although not necessarily of a dishonest nature, must be harmful to the public interest so as to exhibit a clear and serious exploitation of the privileges attributable to the limited liability status of a company. ${ }^{25}$ The courts have sought to explain the necessity of establishing a serious degree of misconduct on the premise that a disqualification order may dramatically infringe upon the commercial liberty of a director in respect of his ability to pursue future employment in the management of a company. ${ }^{26}$ The general approach of the courts in determining the question of a director's potential unfitness is neatly summarised in a passage taken from the judgment of Browne-Wilkinson V-C, in Re Lo-Line Electric Motors Ltd \& Ors ${ }^{27}$. His lordship opined,

"The primary purpose of the section is not to punish the individual but to protect the public against the future conduct of companies by persons whose past records as directors of insolvent companies have shown them to be a danger to creditors and others. Therefore the power is not fundamentally penal. But if the power to disqualify is exercised, disqualification does involve a substantial interference with the freedom of the individual. It follows that the rights of the individual must be fully protected. Ordinary commercial misjudgement is in itself not sufficient to justify disqualification. In the normal case, the conduct complained

22 Ibid, at p 176

23 A director may escape disqualification even if his conduct is considered to be unacceptable or improper, providing of course such conduct falls short of being viewed as unfit, see e.g., Re Austinsuite Furniture Ltd [1992] BCLC 1047, Re Bath Glass Ltd 1988] BCLC 329 and Re Wimbledon Village Restaurant Ltd [1994] BCC 753.

24 See, Re Bath Glass Ltd, ibid.

25 For example, in Re Dawson Print Group Ltd (1987) 3 BCC 322 at p 324 Hoffmann J opined, "There must, I think, be something about the case, some conduct which if not dishonest is at any rate in breach of standards of commercial morality, or some really gross incompetence which persuades the court that it would be a danger to the public if [the respondent] were to be allowed to continue to be involved in the management of companies, before a disqualification order is made."

26 On a more practical level, if a director's culpability was set at a too low a level, the resulting flood of disqualification cases could place the disqualification system under such a strain whereby its very ability to function would be seriously threatened.

27 [1988] BCLC 698. 
of must display a lack of commercial probity although I have no doubt that in an extreme case of gross negligence or total incompetence disqualification could be appropriate." 28

In the majority of decided cases, unfit conduct will be established by evidence of an intentional or reckless disregard of managerial responsibilities or duties, ${ }^{29}$ an obvious and serious (if not persistent) failure to comply with provisions of the companies' legislation, ${ }^{30}$ or a combination of the above failings. ${ }^{31}$ A finding of unfit conduct may often be expected to exceed evidence of conduct resulting in a mere breach of a fiduciary duty, ${ }^{32}$ or a breach of duty which results in but a marginal decline in the company's financial position. ${ }^{33}$ A disqualification order will be more readily imposed where managerial misconduct, being of such a serious nature, prevents the repayment of corporate debts, especially in circumstances where it causes a company to fall into an insolvent state or where the breach inflates a company's already insolvent position.

In some circumstances negligent conduct may also justify disqualification under section 6 of the CDDA 1986. For example, conduct which exhibits the hallmarks of gross incompetence as opposed to mere business folly, may, depending on the consequences of such conduct, give rise to a disqualification order. In assessing the requisite standard of competence to be expected of a director, the standard is measured in accordance with the expectations of a reasonable diligent person as opposed to the standards to be

28 Ibid at $\mathrm{p} 703$.

29 See generally: Re T \& D Services (Timber Preservation \& Damp Proofing Contractors) Ltd [1990] BCC 592, Re Melcast (Wolverhampton) Ltd [1991] BCLC 288, Re GSAR Realisations Ltd [1993] BCLC 409, Re New Generation Engineers Ltd [1993] BCLC 435, Re Hitcho 2000 Ltd [1995] 2 BCLC 63, Re Moorgate Metals Ltd [1995] BCC 143.

30 See generally: Sec of State v Arif [1996] BCC 586, Re Cladrose [1990] BCLC 204, Sec of State v Ettinger, Re Swift 736 Ltd [1993] BCLC 896, Re Firedart Ltd [1994] 2 BCLC 340, Re Park Properties Ltd [1997] 2 BCLC 530.

31 In the majority of cases, it is rare to find proceedings which are commenced on the basis of just one count of alleged misconduct. Whilst it is possible for a disqualification order to be imposed on the basis of only one complaint of misconduct, or to indicate that a specific complaint, taken from a number of complaints of misconduct, was sufficient to justify disqualification, it is more common to find that unfitness will be established in relation to a series of delinquent acts.

32 In Re Barings plc (No5) [1999] 1 BCLC 433 at p 486, Jonathan Parker J observed that it may be possible to find unfit conduct where, for example, a director was responsible for trading at the risk of creditors notwithstanding that the conduct did not involve a breach of duty or an act of wrongful trading under IA 1986, s 214. Further, the learned judge remarked that in addition to finding unfitness in a situation where a director made a negligent mistake it may also be possible to find unfit conduct in a situation where he erred in his judgment. However, with the greatest respect, such observations must be considered doubtful in accordance with the hitherto accepted interpretation of unfitness, i.e., misconduct of a most serious nature.

33 See generally: Re Time Utilising Business [1990] BCLC 568, Re CSTC Ltd [1995] BCC 173, Secretary of State v Van Hengel [1995] BCLC 545, Re Dominion International Group plc (No2) [1996] 1 BCLC 572, Secretary of State v Cleland [1997] 1 BCLC 437, Secretary of State v Lubrani [1997] 2 BCLC 115. 


\section{Northern Ireland Legal Quarterly [Vol. 53, No. 3]}

expected of a professional businessman. Such an assessment may be regrettable, in so far as it ignores the fact that a director, as a professional businessman, may be expected to possess business skills in excess of those of a reasonable diligent person. However, following, for example, the judgment of Jonathan Parker $\mathrm{J}$ in Re Barings Plc (No 5) $)^{34}$ it is still necessary for the court to consider the director's role and specific duties in respect of the management of the company in which he held office. The learned judge remarked thus,

"... while the requisite standard of competence does not vary according to the nature of the company's business or to the respondent's role in the management of that business - and in that sense it may be said there is a universal standard - that standard must be applied to the facts of each particular case. Hence to say that the Act envisages a universal standard of competence applicable in all circumstances takes the matter little further since it says nothing about whether the requisite standard has been met in a particular case. What can be said is that the court, whilst taking full account of the demands made upon a respondent by his management role, will recognise incompetence in whatever circumstances and at whatever level of management it occurs, from the chairman of the board down to the most junior director. In that sense, there is an element of universality in the courts' approach." 35

Therefore, in accordance with the above approach, the expectations of the reasonable diligent person are assessed as the expectations of a reasonable diligent person occupying a position akin to that held by the respondent. In effect, the standard against which a director's competence will be measured is akin to the standard set by section $214^{36}$ of the Insolvency Act $19866^{37}$ and indeed, the general standard applicable to determine a director's breach of a duty of care as advocated in the Final Report of the Company Law Review Steering Group. ${ }^{38}$

Nevertheless, while the measure of competence required to substantiate a finding of negligence for the purposes of disqualification under section 6 of the CDDA 1986 may share similar characteristics to that which is required by section 214 of the Insolvency Act $1986,{ }^{39}$ it must be stressed that one

34 [1999] 1 BCLC 433.

35 Ibid at $\mathrm{p} 484$.

36 For Northern Ireland see Insolvency (NI) Order 1989, art 178.

37 Section 214(4) provides that: . . . the facts which a director of a company ought to know or ascertain, the conclusions which he ought to reach and the steps which he ought to take are those which would be known or ascertained, or reached or taken, by a reasonably diligent person having both-

(a) the general knowledge, skill and experience that may reasonably be expected of a person carrying out the same functions as those which were carried out by that director in relation to the company, and,

(b) the general knowledge, skill and experience of the director.

38 See, Modern Company Law For a Competitive Economy - Final Report (London, DTI, June 2001) Annex C at p 346.

39 See further, Walters, "Directors Duties: The Impact of the Company Directors Disqualification Act 1986" (2000) 21 Co Law 110. 
would expect the minimum degree of incompetence deemed necessary to justify disqualification under section 6 to be in excess of that which would found a charge of wrongful trading under section 214. For incompetent conduct to validate the imposition of a disqualification order the negligence must substantiate a finding of unfitness, and must be of a gross standard. ${ }^{40}$ However, the extent and degree of negligence, deemed necessary to justify a finding of gross incompetence, is unclear. The inconsistency in seeking to define the hallmarks of gross incompetence may, in part, be illustrated by the language adopted by the courts in equating a negligent act with a finding of unfitness. For example, the expressions, "total incompetence", ${ }^{41}$ "incompetence in a very marked degree", 42 "really gross incompetence" 43 and "incompetence of a very high degree" 44 have all been employed to describe the requisite degree of negligence. While such expressions are indicative of a standard which exceeds an act of mere negligence, the extent by which conduct may be defined at a level in excess of mere incompetence remains blurred. Such inconstancy is exemplified by a number of cases involving a director's failure to involve himself in the affairs of the company. For example, in $\operatorname{Re} A \& C$ Group Services $L t d,{ }^{45}$ prior to suffering ill health, $\mathrm{X}$, a director and majority shareholder of a company had been actively involved in the management of the company's business. The company had been solvent during X's guardianship of its affairs. However, following X's illness, the fortunes of the company declined and in an attempt to halt its demise another director $(\mathrm{Y})$ was appointed to the company's board. Y was entrusted with the day-to-day responsibility of running the company's affairs. However, as a direct consequence of Y's appointment the company's fortunes rapidly declined and the company was subsequently wound up with debts in excess of $£ 413,000$. Y was disqualified for a period of six years and $\mathrm{X}$ for a period of two years. $\mathrm{X}$ was disqualified on the premise that he had continued to act as a director of the company during the period in which $\mathrm{Y}$ controlled its affairs but in so acting, had failed to involve himself in the management of the company's affairs. By contrast, in Re Wimbledon Village Restaurant Ltd, ${ }^{46}$ Michael Hart QC, sitting as a deputy High Court judge, found that W, a director of Wimbledon Village Restaurant Ltd, a company which had been put into creditors' voluntary liquidation with debts of over

40 However, where a director's incompetence causes the company to trade whilst insolvent, the company having no reasonable prospect of meeting creditors claims (a scenario akin to an act of wrongful trading under IA 1986, s 214), the courts have not sought to determine culpability on the basis of establishing gross misconduct, see e.g., Secretary of State v Creegan [2002] 1 BCLC 99. Nevertheless, it may be possible to contend that such conduct should be impliedly viewed as gross misconduct in that the nature of this incompetence conveys a complete misunderstanding of the company's financial standing in a manner which is likely to severely prejudice the interests of corporate creditors.

41 See, Re Lo-Line Electric Motors Ltd [1988] Ch 477 at 486 per Browne Wilkinson $\mathrm{V}-\mathrm{C}$.

42 See, Re Sevenoaks Stationers (Retail) Ltd [1991] Ch 164 at 184 per Dillon LJ.

43 See, Re Dawson Print Group Ltd [1987] BCLC 601 at 604 per Hoffmann J.

44 See, Re Barings plc (No5) [1999] 1 BCLC 433 at 483 per Jonathan Parker J.

45 [1993] BCLC 1297. See also, Re Continental Assurance Ltd [1997] BCLC 48, and Re Barings plc (No5) [1999] 1 BCLC 433.

46 [1994] BCC 753. See also, Re Austinsuite [1992] BCLC 1047 and Re Cladrose [1992] BCLC 204 
$£ 327,000$, should not be subjected to a disqualification order in so far as W had not played an active part in the management of the company. W became a director of the company as a means of protecting her own position as the unlimited guarantor of the company's overdraft. The deputy judge held that $\mathrm{W}$ should have been entitled to rely on the skill and experience of the company's other two directors.

\section{The Requisite Standard of Proof}

As a contravention of section 6 invokes no form of criminal liability, the assessment of whether a director's conduct is of an unfit nature will be determined by the civil standard of proof, that is, on the balance of probabilities. Given the civil nature of the proceedings, it follows that hearsay evidence and findings of primary and secondary fact will be more readily admissible than had the proceedings been dealt with under the criminal law. Further, as section 6 proceedings are of a regulatory as opposed to criminal nature, it is probable that Article 6 of the European Convention on Human Rights ${ }^{47}$ will have limited application. ${ }^{48}$

Nevertheless, because allegations made in the course of disqualification proceedings may invoke very serious insinuations of personal misconduct, in some instances the courts have failed to interpret the civil standard of proof in its purest form, instead, interpreting the provision as one whereby a director's culpability must be established at a standard which is reasonably conclusive of a finding of unfitness. For example, in Re Polly Peck International plc, ${ }^{49}$ Lindsay $\mathrm{J}$, opined that the court should, in accordance with the quasi-penal nature of a disqualification order, seek to give a director the benefit of any reasonable doubt in respect of determining culpability. The learned judge remarked,

47 The Human Rights Act 1998 gives effect to the rights and freedoms guaranteed under the European Convention of Human Rights (ECHR). According to ECHR, art 6(1): "In the determination of his civil rights and obligations or of any criminal charge against him, everyone is entitled to a fair and public hearing within a reasonable time by an independent and impartial tribunal established by law." Following Saunders v United Kingdom [1997] BCC 872, art 6(1) is especially pertinent in instances of self-incrimination, i.e., where the use of statements made under compulsion under the Companies Act 1985 to Department of Trade and Industry inspectors are used in a subsequent criminal trial against the person making the statement. Disqualification cases have not been found to be within the ambit of art 6(1), largely because disqualification is regarded by both the domestic courts, see $R$ v Secretary of State for Trade and Industry, ex parte McCormick [1998] BCC 379 and by the ECHR, see, DC, HS and AD v United Kingdom [2000] BCC 710, as a civil regulatory matter, and not a criminal charge. See also, Re Westminster Property Management Ltd [2001] BCC 121.

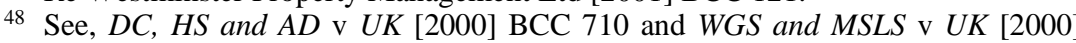
BCC 719. However as observed in the latter case, the fact that disqualification proceedings are to be treated as regulatory civil proceedings and not criminal proceedings for the purposes of art 6(1) will not remove the applicant's right to a fair hearing. Following EDC v United Kingdom [1998] BCC 370, delays in the prosecution of civil proceedings against a director under the CDDA 1986 may constitute a violation of art 6(1). See also, Re Abermeadow Ltd [2001] BCC 724.

49 [1994] 1BCLC 574. See also, Re Living Images Ltd [1996] 1 BCLC 348 and Re Swift 736 Ltd [1993] BCLC 1. 
"Where a provision, here s 6(1)(b), whilst not wholly or even primarily penal in intent, is none the less plainly quasi-penal in effect, it would, in my view, be wrong of a court, unless constrained to do so, to make the threshold which a complainant has to cross other than, and certainly not lower than, whatever Parliament shall by its language have provided." 50

Although more recent judgments have reiterated the necessity for the application of the civil standard of proof as opposed to a criminal or some form of quasi criminal standard, ${ }^{51}$ in practice, given the courts' reluctance to afford the concept of unfit conduct a more liberal definition, there is a danger that the standard of proof may continue to be determined in a manner which is cautious of an affirmative allegiance to the civil standard of proof. While such an approach may serve to safeguard the interests of company directors, it is one which may seriously restrict the effectiveness of the disqualification system and as such cause prejudice to the public interest.

\section{The Effectiveness of Section 6 of the CDDA 1986}

Notwithstanding that it is a problematic task to gauge the effectiveness of section 6 , it is suggested that the success or otherwise of the provision may, in the first instance, be tentatively measured by considering whether the number of disqualification orders hitherto imposed provides evidence of an effective and workable provision. In this respect, DTI statistics confirm a progressive increase in the annual number of disqualification orders imposed under section 6. For example, between the years 1992-1995, an annual average of approximately 400 disqualification orders were imposed, whereas for the period 1995-1997 the annual average had risen to approximately 900 disqualifications, and between 1997-2001, the annual average had escalated to approximately 1300 disqualifications. ${ }^{52}$ The impressive percentage growth in disqualification orders between 1995 and 2001 is indicative of a positive advancement in the enforcement of section 6 . The increase is even more striking when, compared to the period 1990 to 1995, the period 1995 to 2000 witnessed an approximate decline of 40 per-cent in the total number of insolvent liquidations; statistics which suggest that within this latter period there was a significant decline in the pool of delinquent directors. However, while the statistics confirm a sustained increase in the number of section 6 disqualifications, the apparent success of the provision may be unrealistically

50 Ibid, at p 581.

51 See e.g., the judgment of the Court of Appeal in Secretary of State v Deverell [2000] 2 All ER 365, at p 377.

52 For the period 2000-01, the number of disqualification proceedings issued under section 6 totalled 1,456. As a result of these proceedings 1,548 disqualifications orders were imposed. Obviously, in some cases, disqualification proceedings would have been commenced in circumstances where more than one delinquent director was involved in the management of the insolvent company. (The 2000-01 figures represent a small increase (a total of 8 ) in the number of disqualifications imposed under s 6 for the period 1999-2000 but an increase of 264 orders against the period 1998-99). Of the 1,548 disqualified directors, 887 were disqualified for a period of between two and five years. Only 47 directors were disqualified for a period of between 11 and 15 years. See, The Insolvency Service Annual Report and Accounts 2000-01, at http://www.insolvency.gov.uk. 
embellished. For example, between the periods 1995 to 2000, out of a total of over 70,000 insolvent liquidations, it is remarkable that only 5,808 recorded disqualification orders were imposed under section $6 .{ }^{53}$

\section{The Prosecution of Section 6 Actions}

In accordance with section 7(3) of the CDDA 1986, insolvency practitioners are under a statutory obligation to report to the Department of Trade and Industry (DTI) any director who is suspected of conducting the affairs of a company in an unfit manner. In submitting a report, the office holder must investigate conduct by reference to guidelines set out in Schedule 1 of the CDDA 1986. In forming a view as to whether conduct may be considered unfit, an insolvency practitioner should not take a pedantic view of isolated technical failures, for example, the occasional lapse in filing annual returns. The insolvency practitioner is required to consider matters of conduct on the basis of information acquired in the course of his normal duties and by reference to the books and records available to him. An insolvency practitioner is not obliged to undertake investigations, which he would not otherwise have considered necessary for the purposes of his administration. ${ }^{54}$

The Insolvency Service, a department of the DTI, is, through its Disqualification Unit, responsible for determining whether to commence

53 For this period, given that on average insolvent companies have between 2 to 4 directors, it may be assumed that approximately 160,000 directors were involved in the management of such companies. On the basis of these figures, less than $4 \%$ of all such directors were made subject to a disqualification order under $\mathrm{s} 6$.

54 In 1993, a National Audit Office (NAO) report, see Company Director Disqualification HMSO 1993, containing a survey of 103 insolvency practitioners (IPs) showed that a significant majority of the IPs considered that the CDDA 1986 had been unsuccessful in meeting its objectives. In 1997 Andrew Hicks conducted an independent survey of IPs, see The Disqualification of Unfit Directors: No Hiding Place for the Unfit? (1998) ACCA Research Report 59, at pp15-20 and pp 135-146. Here, of the IPs who responded to the survey, although the vast majority were positive and clear about their professional obligation to report on directors of failed companies many were unsure as to what level of unfitness would be necessary to justify a court disqualification under CDDA 1986, s 6. Attitudes of the IPs to the success of the CDDA 1986 were, as with the 1993 NAO report, unfavourable, and despite a considerable increase in the number of disqualifications between 1992 and 1998, a large majority thought insufficient government funding was a primary reason why a greater number of disqualification proceedings had not been commenced. Although a majority of the IPs considered that disqualification orders were inadequately publicised and difficult to enforce, disqualification was still considered to be a worthy sanction. It is also interesting to note that very few IPs criticised the performance of the Insolvency Service. Indeed, the increased rate in the number of disqualification orders imposed under s 6 is probably attributable to an improvement in the working practices of the Insolvency Service. The improvements were prompted as a result of the 1993 NAO report. The improved performance of the Insolvency Service was highlighted in a follow up report by the NAO, see, HCP 1998-99 No 424. Here the Insolvency Service was shown to have more than doubled the resources spent on disqualification from $£ 9 m$ in $1993-94$ to $£ 22 \mathrm{~m}$ in $1997-98$. Further, it allocated more high-grade and support staff to improve the vetting, targeting and processing of cases. However, it should be noted that the Insolvency Service's annual funding for disqualification cases has not been so dramatically increased since 1997-98. 
proceedings under section 6 . The current success rate of the Unit in the prosecution of actions is most creditable as approximately 94 per-cent of all cases which are prosecuted under section 6 result in the imposition of a disqualification order. However, this figure may overstate the Unit's achievements especially as the policy of prosecuting section 6 cases is unquestionably influenced by financial considerations. As with all government departments, the Unit's funding would appear limited, to the extent that only prosecutions which are virtually certain to result in the imposition of a disqualification order are likely to be pursued. Accordingly, it is probable that many instances of commercially culpable conduct will go unpunished. The disqualification process is a natural slave to the economic pressures and constraints of government funding. ${ }^{55}$

\section{Section 17 CDDA $1986^{56}$ - Evading Mandatory Disqualification}

To establish a director's unfitness under section 6 , the director's conduct must be of a most incompetent standard. As such, it is perhaps surprising to discover that the mandatory nature of a section 6 order may be disturbed by section 17 of the CDDA 1986. Section 17 provides that a director may be granted leave to continue in the management of a specified company or companies in circumstances where he is successfully involved in the management of that company or companies. ${ }^{57}$ In reality, the effect of a section 17 order pulls the public interest consideration in two quite distinct directions. The practical effect of section 17 is one which impliedly contradicts the mandatory nature of section 6 . However, section 17 will only be invoked in circumstances where the imposition of a disqualification order would adversely affect the interests of the specified company; causing prejudice to the company's employees and creditors. ${ }^{58}$ Clearly, the courts must strike a delicate balance in determining public policy considerations, always mindful that in invoking section 17 and thereby allowing an unfit director a "second chance" in respect of the management of the specified company, the public interest may be further prejudiced in circumstances where the director fails to sustain a commitment to the nominated company or, worse still, is a party to future delinquent acts of mismanagement. ${ }^{59}$

55 The public costs involved in respect of the disqualification process include the costs of the Disqualification Unit, the provision of legal aid, social security benefits payable to directors made unemployed as a consequence of disqualification, and the costs incurred by the courts. See generally, Wheeler, "Directors Disqualification: Insolvency Practitioners and the Decision Making Process". (1995) 15 LS 283.

56 In Northern Ireland see 1989 Order, art 20.

57 The courts have an absolute discretion in determining whether leave should be granted. The grant of leave is not reserved for exceptional cases, see Secretary of State for Trade and Industry $\mathrm{v}$ Rosenfield [1999] BCC 413.

58 See e.g., Re Gibson Davies Ltd, [1995] BCC 11, Secretary of State v Barnett [1998] 2 BCLC 64.

59 Where a director is granted leave to act under s 17 and breaches the conditions imposed under the leave agreement, it is probable that he will be severely penalised. For example, in Secretary of State v Davies (6th March 1998 unreported) a director who was made subject to a five-year disqualification period (see, Re Gibson Davies Ltd [1995] BCC 11) breached conditions of a leave agreement and in addition committed further delinquent acts in the management of 
The Insolvency Act 2000 - Reforming the Prosecution of Actions under Section 6 of the CDDA 1986

If the Disqualification Unit was financially unfettered in respect of its ability to commence prosecutions under section 6 , it is most probable that a far greater number of directors would be subject to the threat of disqualification. However, up until 2000, an increase in the number of prosecutions under section 6 would have inevitably collapsed an already overburdened court system. Evidence of the strain on the court system may be illustrated by the fact that during the period 1997 to 2001, as an annual average, in excess of 1000 cases were pending prosecution. Further, for the period 2000-01, 58 per-cent of section 6 cases had not been concluded within two years from the commencement of proceedings and as such exceeded the two year limit specified by section 7(2) of the Company Directors Disqualification Act 1986. ${ }^{60}$ Indeed, had it not been for the courts' willingness to adopt a summary form of procedure, the strain on the disqualification system would have been far more transparent. In 2000-01, the summary form of procedure (the Carecraft procedure), ${ }^{61}$ was employed in approximately 30 per cent of all section 6 cases. Basically, the procedure provides that a director is permitted to reach an agreement with the Secretary of State to proceed to court on the understanding that a disqualification order will be made for a pre-determined period.

By 2000, the disqualification system had, in respect of section 6 of the CDDA 1986, been stretched to a point of optimum capacity to the extent that its reform was an essential pre-requisite in seeking to safeguard its future efficiency. Clearly, a fundamental requirement for the reform of the disqualification system was to devise a more competent mechanism for the prosecution of section 6 cases and to this end the enactment of the Insolvency Act $2000^{62}$ may afford a viable means of attaining this goal. As a result of the Insolvency Act $2000,{ }^{63}$ section 1A of the CDDA 1986 now permits the Secretary of State to accept a disqualification undertaking as an

the nominated company. As a consequence of his conduct, the director was disqualified for 12 years. It is suggested that if the director had not previously been disqualified and in breach of the leave agreement, the penalty would have been significantly less severe.

60 See, The Insolvency Service Annual Report and Accounts 2000-01, at http:// www.insolvency.gov.uk.

61 This type of summary procedure was first sanctioned by Ferris $\mathbf{J}$ in Re Carecraft Construction Co Ltd [1994] 1 WLR 172. Whenever a Carecraft application is made, the applicant must:

(a) except in simple cases where the circumstances do not merit it or when the court otherwise directs, submit a written statement containing in respect of each respondent any material facts which (for the purposes of the application) are either agreed or not opposed (by either party); and,

(b) specify in the written statement or, a separate document, the period of disqualification which the parties will invite the court to make or the bracket (i.e. $2-5$ years; $6-10$ years; $11-15$ years) into which they will submit that the case falls.

62 In relation to the undertaking procedure and general reforms to disqualification procedures, IA 2000, ss 5,6,7,8 and Sch.4 were brought into force on April 2, 2001 by the Insolvency Act 2000 (Commencement No 1 and Transitional Provisions Order) - (SI No 766).

63 See, IA 2000, s 6. 
alternative to the imposition of a disqualification order. ${ }^{64}$ The Secretary of State may accept an undertaking if it appears expedient in the public interest to do so. ${ }^{65}$ In determining whether to accept a disqualification undertaking, the Secretary of State may take account of any matter other than previous criminal convictions. ${ }^{66}$

Therefore, in accordance with the statutory undertaking procedure a defendant will agree to refrain from acting as a director or in any other capacity specified by s 1A(1)(a) and (b) of the CDDA 1986, for a predetermined period. ${ }^{67}$ As with a disqualification order, the minimum duration for an undertaking is two years ${ }^{68}$ and the maximum period, fifteen years. ${ }^{69} \mathrm{~A}$ person who agrees to an undertaking may, in accordance with section 17 of the CDDA 1986, still apply for leave to continue to act in a capacity specified by s.1A(1)(a) of the CDDA 1986.

The principal objective of the statutory undertaking procedure will be to significantly reduce the need for disqualification actions to proceed by way of a full trial. In the light of an ever-expanding number of disqualification cases, it is to be expected that the statutory undertaking procedure will significantly reduce the pressure on the court system and considerably reduce the costs incurred by the parties involved in disqualification proceedings. As such the statutory undertaking procedure will advance the advantages of the Carecraft procedure in a most logical way. Indeed, the merits of the undertaking procedure may completely extinguish any future need for section 6 disqualification proceedings to be determined by way of the Carecraft procedure.

The statutory undertaking procedure will also permit the resources of the Insolvency Service to be more effectively taken up with the prosecution of cases in which there is a real dispute between the parties, either in relation to the extent or nature of the alleged misconduct, or to a disputed period of disqualification. Further, it may be assumed that the efficiency of the statutory undertaking procedure will permit the Insolvency Service to

64 The new undertaking procedure only applies to disqualification cases falling within the terms of CDDA 1986, ss 6 and 8. Section 8 provides that following a DTI investigation a person may be disqualified as a director on the ground that the person is unfit to be concerned in the management of a company and that the disqualification order would be in the public interest. The maximum period of disqualification under s 8 is fifteen years. Article 11 of the 1989 Order is the Northern Ireland equivalent.

65 See, CDDA 1986, s 2A.

66 CDDA 1986, s 1A (4), inserted by s 6(2) IA 2000. The Secretary of State may take account of all matters even if the defendant may be criminally liable in respect of such matters.

67 CDDA 1986, s 1A(1)(a)\&(b) contains exactly the same restrictions as those contained in CDDA $1986 \mathrm{~s} 1$, as amended by IA 2000, s 5, namely a person who is made the subject of a disqualification order will not be permitted to be "a director of a company, act as a receiver of a company's property or in any way, whether directly or indirectly, be concerned or take part in the promotion, formation or management of a company unless (in each case) he has the leave of the court, and (b) will not act as an insolvency practitioner".

68 The minimum period does not apply to undertakings or disqualification orders in respect of CDDA 1986, s 8.

69 CDDA 1986, s 1A(2) as inserted by IA 2000, s 6(2). 
prosecute disqualification cases with greater speed and possibly in greater numbers. However, such enthusiasm may need a degree of caution. Although in one sense the statutory undertaking procedure will reduce the pressure on the financial and human resources of the Disqualification Unit, the additional financial and human resources involved in managing and administrating disqualification undertakings may negate some part of any of the expected economic gains. In addition, an expected increase in the number of section 6 prosecutions may be tempered by the hitherto accepted interpretation of case precedents which establish that only the very serious instances of corporate malpractice will justify disqualification under section 6. In effect, the Disqualification Unit's past history of pursuing prosecutions involving only the most serious examples of commercially culpable behaviour may adversely inhibit any substantial increase in the future number of attainable prosecutions.

Although it may be expected that the statutory undertaking system will improve the efficiency of the present disqualification system, conversely, it is possible to contend that it may cause prejudice to the public interest. For example, as a consequence of the statutory undertaking procedure, matters relating to the accountability of delinquent directors will largely be dealt with in the absence of judicial and public scrutiny. Although the Secretary of State must include in the register of disqualified directors such particulars which he considers appropriate of disqualification undertakings accepted by him, ${ }^{70}$ the CDDA 1986 fails to define the extent and nature of "such particulars". Accordingly, the Act does not specifically require the publication of the issues, facts and circumstances that may give rise to an undertaking, or factors which are relevant to determining the length of an undertaking. ${ }^{71}$ Not only will disqualification cases be dealt with "behind closed doors" but once an undertaking is agreed, the courts will only be called upon to consider the merits or otherwise of the undertaking in a situation where a defendant applies to have its duration varied. The power of the court to vary the duration of an undertaking is provided for by s $8 \mathrm{~A}$ of the CDDA $1986 .{ }^{72}$

Therefore, in contrast with the Carecraft procedure, other than where a director makes an application under s 8A, the undertaking procedure will provide no means of judicial scrutiny as to the nature and extent of an agreed disqualification period. In respect of disqualification proceedings under

70 See, CDDA 1986, s 18(2A), inserted by IA 2000, s 5 . The register of disqualification orders is provided for by art 21 of the 1989 Order in Northern Ireland.

71 However, following the recent decision of the Court of Appeal in Sec of State v Davies, Re Blackspur Group plc (unreported, $13^{\text {th }}$ September 2002) affirming the first instance decision of Patten J [2001] 1 BCLC 653, the acceptance of an undertaking may be made conditional on the inclusion of a statement setting out the facts surrounding a finding that a director's conduct was of an unfit nature. Whether the Secretary of State requests such a statement will be a matter for his discretion, although it is probable that such a request will be a common condition attached to the acceptance of future undertakings.

72 Inserted by IA 2000, s 5. Section 8A(1) provides that: "The court may, on the application of a person who is subject to a disqualification undertaking - (a) reduce the period for which the undertaking is to be in force, or (b) provide for it to cease to be in force. 
section 6 of the CDDA 1986, the courts will generally cease to operate as the nominal guardian of justice and the protector of the public interest.

A legislative procedure which permits the acceptance of formal undertakings and as such is devoid of the adverse publicity and costs associated with a full trial may also be criticised in so far as it fails to offer a sufficiently effective deterrent in comparison to a court imposed disqualification order. Further, as the statutory undertaking system provides an attractive and far less expensive alternative to court proceedings, its expediency may serve as an economic incentive for the parties involved to agree to an undertaking, the duration of which may be fixed for a period which is disproportionate to the nature and extent of the defendant's conduct. As the factual circumstances surrounding the terms of a disqualification undertaking may not always be in the public domain, the existence of this economic incentive may prove to be no more than conjecture, but as the primary justification for the undertaking procedure is, itself, coloured by economic necessity, then in terms of the public interest, this concern may be viewed with some anxiety. Apprehension may be especially justified in the more serious instances of commercially culpable conduct where both the Disqualification Unit and defence may, in an attempt to save time and reduce costs, accept a disqualification undertaking the duration of which may have been for a more extensive period had the case proceeded by way of a full trail. While the adoption of the statutory undertaking procedure represents an essential reform in maintaining the efficiency of the disqualification system, the procedure, given its availability in all uncontested disqualification cases, should be viewed with some degree of concern.

In seeking to capitalise on the advantages of the statutory undertaking procedure but in an attempt to minimise its potential prejudice to the public interest, it is suggested that the procedure's availability should have been restricted to cases warranting a disqualification period of up to a maximum of five years, that is, cases involving less serious instances of unfit conduct and falling within the lower bracket of the disqualification periods set out in Re Sevenoaks Stationers. ${ }^{73}$ In an attempt to mitigate costs, the Carecraft procedure could have been employed in all other undisputed cases. The Carecraft procedure saves the court and the parties involved in disqualification proceedings the time and expense that would otherwise have been incurred had the application proceeded to a full trial, but unlike the statutory undertaking procedure, retains the advantage of permitting the courts (albeit in exceptional circumstances) to overturn or adjust the findings of any agreement made between the defendant and the Secretary of State. It is suggested that had the prominence of the Carecraft procedure been maintained, the courts would have retained some nominal form of safeguard in respect of the public interest in cases involving more serious instances of commercially culpable behaviour.

\section{The Future Reform of Section 6 of the CDDA 1986}

While the standard of culpability under section 6 of the Company Directors Disqualification Act 1986 may be criticised on the basis that the conceptual boundaries of "unfitness" are vague and as such liable to produce

73 [1991] Ch 164. 
inconsistency, the term "unfit conduct" does at least serve to reinforce the provision's intention of seeking to penalise only serious instances of managerial malpractice. However, as virtually all prosecutions under section 6 are instigated in circumstances indicative of misconduct which is of a blatant nature, the resulting case precedents which identify, establish and set the requisite norm for determining the standard of unfitness, are comprised of only the most obvious examples of delinquent conduct. Although the term "unfit conduct" is absent of any specific definition, in practice, it is probable that the Disqualification Unit and the courts have inadvertently exaggerated the seriousness of the degree of misconduct required to merit conduct being labelled as unfit. At present, a director may escape being labeled unfit, even in circumstances where his conduct is considered to be of an unacceptable nature. ${ }^{74}$ Accordingly, it is suggested that section 6 is failing to adequately police the activities of directors who, in abusing or neglecting the standards and duties incumbent upon their positions, conduct the affairs of a company in a manner prejudicial to the public interest.

Therefore, as a matter of fundamental reform and in an attempt to fulfil its primary purpose of protecting the public interest, it is submitted that culpability under section 6 should be set at a standard which is more appropriate to a finding that a director's conduct exceeded mere business folly and as a result was prejudicial to the public interest. Further, any revised test should exhibit a greater degree of certainty and consistency in respect of identifying conduct which exceeds mere business folly. Accordingly, it is submitted that section 6 could be reformed to the extent that a director of an insolvent company should, in holding a position of commercial responsibility, be made subject to a disqualification order in circumstances where the affairs of the insolvent company were conducted in a manner prejudicial to the public interest, to the extent that the director's conduct was of a standard which could not be equated with one to be reasonably expected from a director occupying a similar type of management position to that held by the defendant. In determining whether a director's conduct caused prejudice to the public interest, it is suggested that prejudicial conduct would prima facie be established in circumstances where the director's conduct resulted in commercial damage of more than of a trivial nature. ${ }^{75}$

In terms of the standard to be expected of a "reasonable director," much would depend upon the nature and size of the business in which the director was involved and any specialist skills which the director possessed. For example, a finance director with a professional accountancy qualification or with a considerable degree of experience in financial matters would be expected to possess a higher degree of proficiency than a finance director who had no formal qualifications, or little financial experience. However, in all cases, a director's expected standard of proficiency would be assessed on the basis of a standard to be reasonably expected of a director occupying a similar type of management position to that held by the defendant.

74 See, Re Bath Glass Ltd [1988] BCLC 329, Re Austinsuite Furniture Ltd [1992] BCLC 1047, Re Wimbledon Village Restaurant Ltd [1994] BCC 753.

75 Prejudicial conduct is damaging conduct which is caused in a commercial as opposed to an emotional sense. By analogy, see e.g., the judgment of Harman $\mathrm{J}$ in Re Unisoft Group Ltd (No3) [1994] 2 BCLC 609 at 611. 
Therefore, in the given example, even an inexperienced finance director would be expected to exhibit a degree of proficiency to be reasonably expected of a finance director involved in the management of a company of a comparable size and nature.

In many respects, the reformed test advanced to determine culpability under section 6 , hereafter referred to as the prejudice based test, echoes the one prescribed to determine a director's liability under section 214 of the Insolvency Act $1986 .{ }^{76}$ However, in attaching a standard of proficiency to be measured in accordance with the standards expected of a "reasonable director", the benchmark of competence expected of a director would exceed that of a reasonable diligent person so prescribed by section 214 of the Insolvency Act 1986. ${ }^{77}$ The prejudice based test would also differ from the section 214 test in so far as the threshold of proficiency against which a director's culpability would be measured would include all types and degrees of commercial misconduct (this would naturally include all matters currently prescribed by Schedule 1 of the CDDA 1986) as opposed to conduct which specifically related to an act of wrongful trading. Accordingly, unlike the determination of liability under section 214 , the prejudice based test would not require any proof that at some time prior to the commencement of the winding up of the company, the director in question knew or ought to have concluded that there was no reasonable prospect that the company would avoid going into insolvent liquidation. ${ }^{78}$

76 To establish a director's prima facie liability under section IA 1986, s 214, the liquidator must show that at a specified time prior to the liquidation of the company, the director, in conducting the affairs of the company, was aware or ought to have been aware that there was no reasonable prospect of the company avoiding liquidation. In determining whether a director ought to have been aware that there was no reasonable prospect of the company avoiding liquidation, section 214(4) provides that: ". . . the facts which a director of a company ought to know or ascertain, the conclusions which he ought to reach and the steps which he ought to take are those which would be known or ascertained, or reached or taken, by a reasonably diligent person having both-

(a) the general knowledge, skill and experience that may reasonably be expected of a person carrying out the same functions as those which were carried out by that director in relation to the company, and,

(b) the general knowledge, skill and experience of the director.

77 Although the courts have exhibited a reluctance to identify a director's standard of care other than at the level of an ordinary diligent or prudent person, such reluctance is most probably born of a perceived (but probably artificial) difficulty on the part of the judiciary in identifying an appropriate professional standard to be applied to determine an objective measure for calculating a director's standard of care. The reluctance may also be explained on the basis that the judiciary has historically veered away from involving itself in monitoring the effectiveness of business decisions and methods relating to business efficiency, instead they have left this role to the company's shareholders. See further, Parkinson, Corporate Power and Responsibility (Oxford, Clarendon Press, 1993), at pp 97-113.

78 In relation to IA 1986, s 214 the selection of a specified date will often be problematic, especially where the company's financial records are incomplete, or, in some cases, non-existent. In seeking to maximise the amount of the director's potential contribution, the liquidator will seek to select a time period which accentuates the possibility of the highest attainable contribution. However, whilst seeking to maximise the amount of the contribution, the liquidator must ensure 
Although under this revised prejudice based test, disqualification would be determined in accordance with the standards to be expected of a "reasonable director," it is submitted that there should be a statutory defence to a charge of causing prejudice to the public interest. The said defence would be forged in a manner akin to the defence provided by section 214(3) of the Insolvency Act 1986 in respect of an allegation of wrongful trading. ${ }^{79}$ Therefore, it is suggested that the defence would operate in circumstances where, notwithstanding evidence of prejudicial conduct, a director took successful steps to alleviate the extent and degree of prejudice which may have otherwise been caused to the public interest had there been no such intervention. ${ }^{80}$ However, it is contended that the defence would not override the obligatory imposition of a disqualification order or undertaking under section 6, rather, it would provide the court or Secretary of State with a discretion to reduce the duration of the disqualification or undertaking period to reflect the extent by which the director sought to alleviate the extent of the prejudicial conduct. Although mitigating factors may currently be considered in setting disqualification periods, it is suggested that the creation of a statutory defence would, in anticipation of potential disqualification proceedings, more readily promote directors to minimise the extent of any prejudice caused to the public interest.

\section{Reforming the Nature of the Penalty}

Under section 6 of the CDDA 1986, a finding of a director's unfitness necessarily implies the existence of a serious instance(s) of misconduct which for the protection of the public interest demands the imposition of a disqualification order. If, however, a director's culpability was to be determined by the prejudice based test, then clearly the necessity of imposing a mandatory disqualification penalty would need to be reconsidered given the less arduous nature of the threshold of misconduct required to justify disqualification. Indeed, under the prejudice-based test it would appear logical to suggest that the minimum disqualification period could safely be reduced to a period of one year without detrimentally affecting the public interest. Although one could go further and advance the complete abrogation of the mandatory penalty, it is submitted that the degree of misconduct

that the specified date is conclusive of a finding that, as of that date, there was no reasonable prospect of the company avoiding liquidation. The selection of the specified date is crucial and will, if it does not accurately prescribe the period of wrongful trading, be fatal to the liquidator's case, see e.g., Re Sherborne Associates Ltd [1995] BCC 40. For a detailed analysis of accounting issues illustrating the difficulties faced by a liquidator in assessing whether the directors of a company were correct in their determination that the company's continued trading would not be conclusive of it going into liquidation, see Re Continental Assurance Co [2001] BPIR 733.

79 The defence is represented by IA 1986, s 214(3) and will apply to a director where, on first becoming aware that there was no reasonable prospect that the company could avoid going into insolvent liquidation, the director took every step with a view to minimising the potential loss to the company's creditors.

80 For this defence (unlike IA 1986, s 214 (3)), it is submitted that a director would not need to take every step with a view to minimising any potential loss to the company's creditors. However, obviously the more steps that were successfully taken then the greater the likelihood that the director would qualify for a more significant reduction in the disqualification period. 
deemed necessary to justify disqualification under the prejudice based test would, in terms of protecting the public interest, still justify a mandatory disqualification period of one year. Further, the maintenance of a mandatory penalty would serve as a positive deterrent in discouraging directors from participating in delinquent conduct.

In addition, it is also suggested that an undertaking/disqualification order should be capable of being suspended for up to a maximum period of five years. Under such a scheme, the terms of the suspended undertaking/disqualification order would allow a director to escape the immediate consequences of an undertaking/disqualification order. If however, during the period of the suspended order, the director was made subject to a subsequent undertaking/disqualification order, then, in addition to the duration of this subsequent order, the director would be made subject to the additional period of disqualification as represented by the suspended order. It is submitted that the suspended undertaking/disqualification order would only be applicable in cases which would otherwise have justified an undertaking/disqualification order for up to a maximum period of five years. In cases involving disqualification periods in excess of five years, it is submitted that the power to grant leave to act under section 17 should be abrogated given that in such cases the economic advantages of permitting a director to continue to act in respect of a nominated company will rarely, if ever, outweigh the court's desire to protect the public interest from a potential reoccurrence of very serious misconduct.

In respect of cases where the suspended order was applicable, section 17 of the CDDA 1986 would be rendered redundant. The adoption of the suspended order would allow the courts to exercise leniency in cases where, for example, a director exhibited a strong potential to reform past instances of misconduct. However, where the exercise of such leniency was subsequently betrayed by a director's misconduct in the future management of a company, the terms of the suspended order would have the effect of severely punishing the betrayal, as the director would in effect be obliged to serve two consecutive periods of disqualification. The adoption of the suspended order would also have the effect of reducing the costs incurred under the disqualification process because under the new undertaking procedure the grant of a section 17 order will necessarily involve court proceedings. ${ }^{81}$

A final point in the context of the disqualification penalty concerns the present sanction for a breach of a disqualification order, namely a maximum term of two years imprisonment and/or fine. ${ }^{82}$ It is contended that such a penalty is far too lenient to the extent that it may encourage disqualified directors to continue to act in a managerial position in contravention of the terms of a disqualification order; especially in the capacity of a de facto ${ }^{83}$ or

81 CDDA 1986, s 17 provides that an application for leave to promote or form a company must be made to any court with a jurisdiction to wind up companies and that an application for leave to take part in the management of a company must be made to a court having a jurisdiction to wind up that company.

82 See, CDDA 1986, s 13; art. 17 of the 1989 Order in Northern Ireland.

83 See, Re Kaytech International plc Potier $v$ Secretary of State for Trade and Industry [1999] BCC 390. 
shadow director. ${ }^{84}$ At present, a disqualified director may consider that the financial rewards of participating in a managerial capacity outweigh the risk of his detection and the possibility of imprisonment or a fine. ${ }^{85}$ Accordingly, as a matter of reform, it is suggested that a breach of a disqualification order should be punished by a criminal sanction of a minimum term of imprisonment of one year and fine and a maximum term of imprisonment of five years and fine.

\section{Increasing the Effectiveness of the Disqualification Process}

The introduction of the statutory undertaking procedure will undoubtedly reduce the number of section 6 cases which have hitherto been determined by the courts and accordingly reduce the pressure on the resources of the Disqualification Unit in the preparation and prosecution of such cases. However, given that the majority of disqualification cases under section 6 will now be by way of the new undertaking procedure, it is likely that the Disqualification Unit will encounter additional burdens in respect of managing and administering the procedure. Also, if, as suggested, the standard of culpability for section 6 cases was to be determined by the application of the prejudice based test, it is evident, given the less stringent standard of culpability required to justify disqualification, that the resulting flood of disqualification cases could seriously swamp the disqualification system.

Therefore, in an attempt to safeguard the efficiency of the disqualification process it is suggested that a far greater number of disqualifications cases could, prima facie, proceed via section 10 of the CDDA $1986 .{ }^{86}$ Section 10 provides that the court may, of its own volition, impose a disqualification order in circumstances where, following an application from the company's liquidator, the court finds a person is liable to make a contribution under section 213 or 214 of the Insolvency Act $1986 .{ }^{87}$ The court may, at its discretion, impose a disqualification order for up to a maximum period of fifteen years. ${ }^{88}$

84 See, Secretary of State v Deverell [2000] 2 All ER 365.

85 It should be noted that the risks of detection may have increased as a result of the "Disqualification Hotline", a telephone service to which members of the public can report any person they believe to have been acting in contravention of a disqualification order. As of October 2001, over 2,500 calls had been made to the Hotline since its launch in January 1998, with approximately one third of the said calls resulting in an investigation.

${ }^{86}$ For Northern Ireland see art 13 of the 1989 Order.

87 The equivalent Northern Ireland provisions are arts 177 and 178 of the Insolvency (NI) Order 1989.

88 In respect of establishing liability under IA 1986, s 213 it must be shown that a person was knowingly a party to the carrying on of the company's business and was aware that the company had no reasonable prospect of being able to re-pay its debts, see, Re Patrick Lyon Ltd [1933] 1 Ch 786 and $R v$ Grantham [1984] QB 675. IA 1986, s 214 was introduced following the recommendations of the Cork Committee Report (Cmnd. 8558), see paras: 1781-1806. Section 214 seeks to penalise a director in circumstances where the director allows the company to continue to trade, at a date up to the commencement of the company's winding up, when he knew or ought to have concluded that there was no reasonable prospect of the company being able to avoid insolvent liquidation. Where a director is liable 
While at present the courts' ability to impose a disqualification order under section 10 of the CDDA 1986 is comprised of a discretionary power (a power which would be unlikely to be exercised save for where a director's conduct was also deemed to be of an unfit nature) it is suggested that if section 6 of the Company Directors Disqualification Act 1986 was reformed in accordance with the prejudice based test, then in such circumstances, section 10 could also be reformed to the extent that culpability under section 213 or 214 would give rise to an automatic disqualification order. Disqualification could be deemed automatic in so far as if liability was established under section 213 or 214 , it would follow that the necessary degree of culpability would also have been established in respect of the prejudice based disqualification test. ${ }^{89}$

Further it is also suggested that in an attempt to accelerate disqualification actions other than under section 6 of the CDDA 1986, the ambit of section 10 could be extended by, for example, providing for the provision's applicability in respect of misfeasance proceedings under section $212^{90}$ of the Insolvency Act 1986. ${ }^{91}$ Section 212 is a procedural device and provides a summary remedy whereby persons who were involved in the management of a company may be held accountable for any breach of duty, or other act of misfeasance. Proceedings under section 212 may only be pursued where, prior to a company's liquidation, the misconduct which formed the subject matter of the misfeasance claim was capable of being made the subject of an action by the company. ${ }^{92}$ While at present, conduct supporting a misfeasance action may not necessarily justify its description as unfit conduct for the purposes of section 6 of the CDDA 1986, if section 6 was to be reformed in accordance with the prejudice based test, factual circumstances giving rise to a successful action under section 212 would also satisfy the prejudice requirement. Therefore, as with a finding of fraudulent or wrongful trading,

under the terms of s 213 or s 214 the director will, at the discretion of the court, be liable to pay a contribution order into the general assets of the company.

89 However, it must be pointed out that at present the number of actions commenced under IA 1986 ss 213 and 214 are relatively few and as such reform of these provisions will be necessary to accelerate the possibility of commencing more disqualification cases under CDDA 1986, s 10. In proving liability under s 213 the liquidator has a most arduous task in so far as he must establish an intention to perpetrate the fraudulent act, an intention confirmed by proving that the respondent acted in a dishonest manner. While the introduction of s 214 sought to provide a more accessible mechanism by which directors of insolvent companies could be held accountable for acts of wrongful trading, the provision is currently hampered by a number of procedural constraints, see further, Griffin, "Accelerating Disqualification under Section 10 of the Company Directors Disqualification Act 1986" [2002] Insolvency Lawyer 32.

90 In Northern Ireland see art. 177 of the Insolvency (NI) Order 1989.

91 The applicability of CDDA1986, s 10 could (if culpability under CDDA 1986, s 6 was based upon a prejudice based test) also be extended by providing that its ambit should include successful actions brought in respect of proceedings under IA 1986, s 216 (phoenix companies) (art. 180 in Northern Ireland), s 238 (transactions at an undervalue) and s 239 (preferences) (arts 202-203 in Northern Ireland).

92 See generally, Regal Hastings Ltd v Gulliver [1942] 1 All ER 378, [1967] 2 AC 134 and Re D'Jan of London Ltd [1993] BCC 646. 
a director who was found culpable under section 212 could justifiably be made subject to an automatic disqualification order.

\section{CONCLUSION}

Section 6 of the CDDA 1986 aims to penalise the delinquent conduct of company directors who have sought to abuse the advantages afforded by the concept of limited liability and as such the provision affords an essential safeguard to the exploitation of an enterprise culture which all too readily encourages entrepreneurs to risk capital in the pursuit of profit. ${ }^{93}$ Although section 6 represents a potentially effective form of penalty, its effectiveness has thus far been limited by procedural constraints and an austere interpretation afforded to the concept of unfit conduct. While, in respect of section 6 , it is probable that the introduction of the statutory undertaking procedure will increase the efficiency of the disqualification process, it is unlikely whether the new procedure will, in the long term, result in a substantial increase in disqualification orders. Therefore, if section 6 is to achieve a more effective method of penalising and deterring the delinquent activities of directors and thereby serve as a more viable and visible means of protecting the public interest, the measure of culpability required to activate the provision must be subject to reform. In addition, and to ease the burdens of the Insolvency Service, there must also be an alternative and effective means of disqualifying delinquent directors other than by proceedings under section 6 of the CDDA 1986. To this end it is essential to have an expansion in disqualification proceedings under a revised section 10 of the CDDA 1986. Sections 6 and 10 of the CDDA 1986 must be transformed into far more effective weapons if the disqualification process is to more readily attain its objective of protecting the public interest.

While a stricter disqualification regime could be criticised as one which would "discourage legitimate risk-taking, stigmatise business failure and adversely affect the promotion of an entrepreneurial society," 94 it is contended that a more effective system of disqualifying delinquent directors would serve as potent notice of a just and fair regulation of the limited liability company, whereby the exploitation of limited liability would be strictly penalised to the detriment of the delinquent director and the ultimate benefit of the future public interest. Indeed, a stricter disqualification regime would discourage commercial folly, enhance public confidence in the workings of commerce and as such promote a more equitable and responsible entrepreneurial society.

* The author wishes to express his thanks to Professor Dan Prentice, Professor David Campbell and for reading and commenting on an earlier draft of this paper. The author would also like to express his gratitude to the

93 In an attempt to curb the potential exploitation of the limited liability company further measures could be introduced to limit a potential delinquency in company directors, for example, compulsory training courses educating directors in respect of the legal requirements and responsibilities attached to their positions, or a minimum capital requirement for private companies to discourage undercapitalised concerns, see Hicks, "Director Disqualification: Can it Deliver?" [2001] JBL 433 at $451-452$.

94 Ibid at $\mathrm{p} 459$. 
anonymous referee for his/her helpful suggestions. A final vote of thanks to David Capper for his valuable observations and for his assistance with the Northern Ireland references. The opinions expressed within this paper and any errors contained therein are the sole responsibility of the author. 